\title{
Distribution of Synechococcus in the dark ocean
}

\author{
Rumi Sohrin ${ }^{1, *}$, Makishi Isaji ${ }^{1}$, Yoshimi Obara ${ }^{1}$, Sylvain Agostini ${ }^{1}$, Yoshimi Suzuki ${ }^{1}$, \\ Yutaka Hiroe $^{2}$, Tadafumi Ichikawa ${ }^{2}$, Kiyotaka Hidaka ${ }^{2}$
}

\author{
${ }^{1}$ Institute of Geosciences, Shizuoka University, 836 Oya, Suruga, Shizuoka 422-8529, Japan \\ ${ }^{2}$ National Research Institute of Fisheries Science, Fisheries Research Agency, 2-12-4 Fukuura, Kanazawa, Yokohama, \\ Kanagawa 236-8648, Japan
}

\begin{abstract}
Synechococcus is widely distributed in the world's ocean surfaces, and is often found in sediment traps. However, its distribution and ecological importance have not been well studied in meso- and bathypelagic waters. We measured Synechococcus abundance in the Suruga Bay (central Japan) and the subtropical NW Pacific. Synechococcus abundance at depths of $200 \mathrm{~m}$ and below varied from 2.4 to 190 cells ml $^{-1}$, but was in proportion to the surface abundance, suggesting transport of epipelagic populations to greater depths. Surprisingly, Synechococcus was evenly distributed from $200 \mathrm{~m}$ down to $1420 \mathrm{~m}$ (Suruga Bay) or to $2000 \mathrm{~m}$ (subtropical NW Pacific), regardless of season. The contribution of deep Synechococcus to the total population was highest in spring in the Suruga Bay (36 to $77 \%$ ), and lowest in summer in the Suruga Bay (1 to 9\%) and in the subtropical NW Pacific (4 and 10\%). These results suggest effective transport of Synechococcus cells down the water column during productive seasons by attachment to large particles and limited transport under oligotrophic and stratified conditions. Deep Synechococcus abundance decreased from fall to winter in the Suruga Bay, though in filtered deep seawater it did not significantly decrease for $30 \mathrm{~d}$ in the dark, and it increased in a light/dark cycle. Our investigations show that the standing stock of Synechococcus has been significantly underestimated in previous studies of epipelagic waters conducted during productive seasons and that Synechococcus seems to be grazed and to contribute to biogeochemical cycles in the dark ocean.
\end{abstract}

KEY WORDS: Synechococcus · Dark ocean · Vertical distribution · Vertical export Resale or republication not permitted without written consent of the publisher

\section{INTRODUCTION}

Synechococcus is a unicellular photosynthetic prokaryote that is ubiquitous in the world's ocean surfaces (Johnson \& Sieburth 1979, Waterbury et al. 1979). Synechococcus populations are responsible for a significant portion of primary production, in some cases more than half of the total (Gutiérrez-Rodríguez et al. 2010). They are removed by the grazing of microzooplankton, such as nanoflagellates and ciliates (Christaki et al. 1999, 2001) and by viral infection (Suttle \& Chan 1993, 1994).

Despite the demonstrated ecological importance of Synechococcus in the euphotic zone and detection of the cells in the meso- and bathypelagic waters (Fuhrman et al. 1989, Yamaguchi et al. 2002, Vilibi \& Šanti 2008), little attention has been paid to popula- tions in the dark ocean (i.e. meso- and bathypelagic zones). This is understandable because Synechococcus cells were thought to be unlikely to grow in darkness (Six et al. 2004, Timmermans et al. 2005), and are too small to sink below the seasonal picnocline unaided (Michaels \& Silver 1988). However, there are many studies which have detected Synechococcus cells attached to sinking particles in the meso- and bathypelagic waters (Vanucci et al. 2001 and references therein) and in photodetritus on the abyssal sediment (Lochte \& Turley 1988). These studies reveal transport of Synechococcus cells associated with large particles. Recently, other transport processes were suggested, for example, aggregation of Synechococcus cells (Richardson \& Jackson 2007) and winter ventilation (Vilibi \& Šanti 2008). Furthermore, a growing body of evidence shows heterotrophic activity of Synechococcus, i.e. the 
ability to utilize organic substrates (Zubkov et al. 2003, Zubkov \& Tarran 2005), suggesting that Synechococcus can survive in darkness (Cottrell \& Kirchman 2009).

These earlier studies led us to examine how Synechococcus is dispersed throughout the dark ocean. The purpose of the present study is to clarify the abundance and distribution of Synechococcus in the dark ocean and to make inferences about the ecological and biogeochemical roles of the organism. Surprisingly, at depths of $200 \mathrm{~m}$ and below, Synechococcus was evenly distributed regardless of the season or area studied. These deep populations accounted for up to $77 \%$ of total Synechococcus population in the entire water column.

\section{MATERIALS AND METHODS}

Sampling. Seawater was collected in Niskin bottles mounted on a CTD-carousel sampler at Station (Stn) 2 $\left(34^{\circ} 51^{\prime} \mathrm{N}, 138^{\circ} 37^{\prime} \mathrm{E}\right.$, Suruga Bay) and Stn C2700 $\left(27^{\circ} 00^{\prime} \mathrm{N}, 138^{\circ} 00^{\prime} \mathrm{E}\right.$, subtropical NW Pacific), during cruises on board the RV 'Suruga-maru' (Shizuoka Prefectural Research Institute of Fisheries) and RV 'Soyomaru' (National Research Institute of Fisheries Science, Fisheries Research Agency). The sampling location and hydrological conditions are shown in Table 1. Stn 2 is located near the Suruga Trough, at the center of the Suruga Bay, and Stn C2700 is a time-series station on O-Line (Sugisaki et al. 2010). Samplings at Stn 2 were conducted in the uppermost $1000 \mathrm{~m}$ between February 2005 and November 2006, and fulldepth profiles, from the surface to a depth of $20 \mathrm{~m}$ above the bottom $(B-20 \mathrm{~m} ; B=1440 \mathrm{~m})$, were made between April 2007 and May 2008 (Table 2). Sample collection was always started at 10:00 h. At Stn C2700, seawater was taken from the top $2000 \mathrm{~m}$ in August and November 2007 (Table 2). The depth of the euphotic zone (i.e. receiving $1 \%$ of the surface photosynthetic available radiation, PAR) was determined mostly from PAR data taken from the upper $100 \mathrm{~m}$ (Stn 2) and $200 \mathrm{~m}$ (Stn C2700) on previous cruises due to insufficient data obtained in this study. Winter mixed layer depth (MLD) was calculated according to Levitus
(1982), using CTD data obtained in February 2005 to 2008 (Stn 2), and January 2007 and 2008 (Stn C2700).

Measurements. Synechococcus abundance: Seawater samples of Synechococcus were transferred to black plastic bottles and immediately fixed with neutralized formalin (final conc. $1 \%$ ), then stored in a refrigerator. The fixed samples were collected on $0.4 \mu \mathrm{m}$ pore size polycarbonate filters (diameter, $25 \mathrm{~mm}$; Advantec, Japan) under a vacuum pressure of 0.02 to $0.03 \mathrm{MPa}$ within $2 \mathrm{wk}$ of sample collection. The filtration volume was set at between $100 \mathrm{ml}(\leq 50 \mathrm{~m})$ and $1 \mathrm{l}$ $(\geq 100 \mathrm{~m})$ depending on sampling depth, and it took $2 \mathrm{~h}$ on average to filter the latter sample types. The filters were then mounted on glass slides using non-fluorescent immersion oil and coverslips, and kept in a freezer until counting. Yellowish orange fluorescent cells with sizes smaller than $2 \mu \mathrm{m}$ were counted in at least 10 eyepiece fields $(100 \times 100 \mu \mathrm{m})$ using an epifluorescence microscope (BX51, Olympus, Japan) under blue excitation (excitation filter, BP470-490; dichroic mirror, DM505; barrier filter, BA515; Olympus) with a 100x objective lens and 10x eyepiece (Putland \& Rivkin 1999). If fewer than 300 cells were detected on a filter, cells in 1000 fields were counted. It should be noted that Synechococcus abundance might have been overestimated at Stn C2700 because of the frequent occurrence of other small, yellowish orange fluorescent cyanobacteria such as Crocosphaera and Cyanothece, which has been reported in the subtropical oceans (Neveux \& Lantoine 1999, Church et al. 2005).

Chlorophyll a concentration and total prokaryotic abundance: Seawater samples of chlorophyll a (chl a) were placed into amber plastic bottles, and immediately collected on GF/F filters (Whatman). The volume of filtered seawater was set at between $275 \mathrm{ml}(\leq 150 \mathrm{~m})$ and $3270 \mathrm{ml}(\geq 300 \mathrm{~m})$, depending on sampling depth, and either a $25 \mathrm{~mm}$ or $47 \mathrm{~mm} \mathrm{GF} / \mathrm{F}$ filter was chosen, depending on filtration volume. Chl a concentration was measured using a spectrofluorometer (RF-5300, Shimadzu, Japan) after extraction of suspended matter on filters with N, N-dimethylformamide (Suzuki \& Ishimaru 1990).

Samples of total prokaryotic abundance were placed into clear plastic tubes, and fixed with neutralized for-

Table 1. Study area. Location, bottom depth, and euphotic zone and winter mixed layer (MLD) depths

\begin{tabular}{|c|c|c|c|c|c|}
\hline Station & Area & Location & $\begin{array}{l}\text { Bottom depth } \\
\text { (m) }\end{array}$ & $\begin{array}{l}\text { Depth of euphotic } \\
\text { zone }(\mathrm{m})^{\mathrm{a}}\end{array}$ & $\begin{array}{l}\text { Winter MLD } \\
(\mathrm{m})^{\mathrm{b}}\end{array}$ \\
\hline Stn 2 & Suruga Bay & $34^{\circ} 51^{\prime} \mathrm{N}, 138^{\circ} 37^{\prime} \mathrm{E}$ & 1440 & $31-51$ & $86-133$ \\
\hline Stn C2700 & Subtropical NW Pacific & $27^{\circ} 00^{\prime} \mathrm{N}, 138^{\circ} 00^{\prime} \mathrm{E}$ & 5000 & $80-120$ & 47,90 \\
\hline
\end{tabular}


Table 2. Sampling information, temperature (temp.), and nutrient concentrations at $10 \mathrm{~m}$

\begin{tabular}{|c|c|c|c|c|c|}
\hline \multicolumn{2}{|c|}{ Sampling -} & \multirow{2}{*}{$\begin{array}{c}\text { Temp. } \\
\left({ }^{\circ} \mathrm{C}\right)\end{array}$} & \multicolumn{2}{|c|}{ - Data at $10 \mathrm{~m}$} & \multirow[b]{2}{*}{$\begin{array}{l}\mathrm{PO}_{4}{ }^{3-} \\
1)^{1-}\end{array}$} \\
\hline Date & $\begin{array}{l}\text { Depth } \\
\text { range }(\mathrm{m})^{\mathrm{a}}\end{array}$ & & $\mathrm{NO}_{3}^{-}$ & $\begin{array}{c}\mathrm{NH}_{4}^{+} \\
\left(\mu \mathrm{mol} \mathrm{l} \mathrm{l}^{-}\right.\end{array}$ & \\
\hline \multicolumn{6}{|c|}{ Stn 2, Suruga Bay } \\
\hline 22 Feb 2005 & $2-1000$ & 15.3 & 5.84 & 0.05 & 0.42 \\
\hline 22 Apr 2005 & $2-1000$ & 16.4 & 0.68 & 0.52 & 0.16 \\
\hline 13 Jul 2005 & $10-1000$ & 21.9 & 0.45 & $<0.01$ & 0.08 \\
\hline 28 Nov 2005 & $20-1000$ & 20.8 & 1.42 & 0.09 & 0.23 \\
\hline 15 Feb 2006 & $20-1000$ & 13.3 & 11.3 & $<0.01$ & 0.77 \\
\hline 19 Apr 2006 & $4-1000$ & 14.4 & 5.05 & 0.36 & 0.37 \\
\hline 12 Jul 2006 & $2-1000$ & 19.5 & 0.34 & $<0.01$ & 0.09 \\
\hline 27 Nov 2006 & $2-1000$ & 19.1 & 3.04 & 0.04 & 0.29 \\
\hline 24 Apr 2007 & $2-B-20$ & 16.8 & 0.62 & 0.43 & 3.16 \\
\hline 27 Nov 2007 & $2-B-20$ & 20.1 & 2.65 & 0.11 & 0.23 \\
\hline 20 Feb 2008 & $2-B-20$ & 14.0 & 8.34 & 0.09 & 0.65 \\
\hline 16 May 2008 & $2-B-20$ & 19.6 & $<0.01$ & 0.06 & 0.09 \\
\hline \multicolumn{6}{|c|}{ Stn C2700, Subtropical NW Pacific } \\
\hline 31 Aug 2007 & $5-2000$ & 29.3 & $<0.01$ & 0.14 & 0.05 \\
\hline 1 Nov 2007 & $5-2000$ & 26.2 & 0.04 & 0.23 & 0.03 \\
\hline
\end{tabular}

malin (final conc. $2 \%$ ), then preserved in a refrigerator. A volume of 10 to $30 \mathrm{ml}$ of the fixed samples was stained with 4', 6-diamidino-2-phenyl indole (final conc. $0.1 \mu \mathrm{g}$ $\mathrm{ml}^{-1}$ ) and collected on Irgalan black-stained $0.2 \mu \mathrm{m}$ pore size polycarbonate filters (Advantec) within 2 wk of sample collection (Porter \& Feig 1980). Filters were mounted on glass slides and kept frozen until counting. Cells were counted in 10 fields under UV excitation of an epifluorescence microscope (BX51). Abundance of picophytoplankton, that is to say Synechococcus, Prochlorococcus (not detected at Stn 2) and picoeukaryotic phytoplankton, was measured using flow cytometry (see below), and was more than one order of magnitude lower than total prokaryotic abundance. Thus, total prokaryotic abundance could be used as a suitable proxy for heterotrophic prokaryotic abundance.

Methodological check. Comparison between Niskin sampling and siphon sampling: We checked our approach to determining Synechococcus abundance by comparing Synechococcus abundance between Niskin sampling and siphon sampling to determine whether surface Synechococcus could attach itself to the interiors of the Niskin bottles during descent to greater depths. The Suruga Bay has siphon-sampling systems, which supply seawater via polyethylene tubes directly to tanks in the underground basement of a land station, from depths of $397 \mathrm{~m}$ (tube length $3323 \mathrm{~m}$; inside diameter $200 \mathrm{~mm}$ ) and $687 \mathrm{~m}$ (tube length $7273 \mathrm{~m}$; inside diameter $225 \mathrm{~mm}$ ). In these systems, differences between tank water levels and seawater levels generate gravity-driven flow, and seawater passes through the tubes at the maximum flow rate of
$2000 \mathrm{~m}^{3} \mathrm{~d}^{-1}$ without pumping, which gives a turnover time of seawater within the systems of a few hours. We took seawater simultaneously at the land institution (Suruga-Bay Deep Sea Water Aquaculture Research Center, Shizuoka Prefectural Research Institute of Fisheries) by siphon sampling, and at the inlets of polyethylene tubes by Niskin sampling on board the RV 'Suruga-maru' in November 2005 and February 2006. Synechococcus was then counted by epifluorescence microscopy.

Comparison between epifluorescence microscopy and flow cytometry: Generally, Synechococcus cells are counted with flow cytometry, and similar measurements have been reported with flow cytometry and epifluorescence microscopy in epipelagic samples (Putland \& Rivkin 1999, Havskum et al. 2004). However, a decrease in the fluorescence of phycoerythrin (PE) has been shown in subsurface samples when using flow cytometry (Olson et al. 1990), suggesting that epifluorescence microscopy might fail to detect weakly fluorescent Synechococcus cells in deep seawater samples. We compared Synechococcus abundance obtained from flow cytometry and epifluorescence microscopy in samples taken from the water column at Stn 2 in November 2007 and February and May 2008. Samples for flow cytometry measurement were fixed with $20 \%$ glutaraldehyde (electron microscopic grade; final conc. $1 \%$ ) and frozen in liquid $\mathrm{N}_{2}$ (Vaulot et al. 1989). Frozen samples were preserved in a deep freezer until analysis. Synechococcus cells were counted using an EPICS XL (Beckman Coulter) at a medium flow rate for $12 \mathrm{~min}$ (samples from $<100 \mathrm{~m}$ ) or $30 \mathrm{~min}(\geq 100 \mathrm{~m})$. The high flow rate was not used due to the high noise level. The cells were identified within an adequate area (gate) on plots of red fluorescence $(\mathrm{chl}$ a) versus orange fluorescence $(\mathrm{PE})$. A solution of fluorescent beads (Flow Count; size $10 \mu \mathrm{m}$; Beckman Coulter) was added at $2 \% \mathrm{vol} / \mathrm{vol}$ to the samples as an internal reference for the quantification of cell concentration. A vertical series of samples was analyzed and the same gate was applied on the same analysis day. The number of identified Synechococcus cells ranged between $<10$ and $>7000$ cells per sample. Samples collected in May 2008 were measured in triplicate to examine reproducibility (the other samples were measured only once). The reproducibility of epifluorescence microscopy was examined in seawater taken at a depth of $1000 \mathrm{~m}$ at Stn 2 in May 2008 by filtering the seawater in triplicate. To examine procedural blanks, $3.5 \% \mathrm{NaCl}$ solution was processed in the same way as the deep seawater samples $(\geq 200 \mathrm{~m})$, and abundance of Synechococcus, total prokaryotes, and chl a concentration were measured. The procedural blank value was subtracted from the sample values for Synechococcus abundance obtained using flow cytometry. 
Incubation experiments. To examine the tolerance of Synechococcus populations to sunlight deprivation and the response of the deep population to light, dark (Dark Expt) and light manipulation (Light/Dark Expt) incubation experiments were conducted. Seawater samples were collected from depths of 20 and $300 \mathrm{~m}$ at Stn 2 in November 2005 by Niskin sampling (Dark Expt) and from $397 \mathrm{~m}$ in October 2006 by siphon sampling (Light/Dark Expt). To remove grazers, samples were filtered through a GA-55 glass-fiber filter (nominal pore size $0.6 \mu \mathrm{m}$; diameter $9 \mathrm{~cm}$; Advantec) into a 201 polycarbonate spigot bottle in dim light in a laboratory. We selected GA-55 because of its lower retention efficiency for Synechococcus over the other glassfiber filters, such as Whatman GF/A (nominal pore size $1.6 \mu \mathrm{m})$ and GF/C (1.2 $\mathrm{m})$ (data not shown). Recovery of Synechococcus in the filtrate in Dark Expt was 66\% $(20 \mathrm{~m})$ and $45 \%(300 \mathrm{~m})$. The bottles used for dark incubation were covered with aluminum foil. Filtered samples were incubated individually at $20^{\circ} \mathrm{C}$ (seawater temperature at $20 \mathrm{~m}$ at the time of sampling) in the dark for $30 \mathrm{~d}$ (Dark Expt), and in a $12 \mathrm{~h}$ light:12 h dark cycle or in continuous darkness for $14 \mathrm{~d}$ (Light/Dark Expt). Irradiance was set at $60 \mu \mathrm{mol}$ photons $\mathrm{m}^{-2} \mathrm{~s}^{-1}$ using cool white lights, which was equivalent to the irradiance at $30 \mathrm{~m}$ at Stn 2. Subsamples were periodically obtained from a spigot and Synechococcus abundance was counted by epifluorescence microscopy.

\section{RESULTS}

\section{Methodological considerations}

Comparison between Niskin sampling and siphon sampling

Synechococcus abundance in the mesopelagic Suruga Bay seawater was 66 to 250 cells ml $^{-1}$ for Niskin sampling and 63 to 207 cells $\mathrm{ml}^{-1}$ for siphon sampling. There was no significant difference between the Synechococcus abundance obtained with Niskin and siphon sampling (paired Student's $t$-test, $\mathrm{n}=4, \mathrm{p}>0.05$ ), and we concluded that surface Synechococcus cells were unlikely to be drawn down to deeper waters by Niskin sampling.

\section{Comparison between epifluorescence microscopy and flow cytometry}

Meso- and bathypelagic Synechococcus cells were detected as yellowish orange fluorescent cells under blue excitation by epifluorescence microscopy in a similar way to the epipelagic cells (Fig. 1). However,
Synechococcus abundance obtained by epifluorescence microscopy was significantly lower than that obtained by flow cytometry through the water column (Fig. 1). Model II linear regression between epifluorescence microscopy $(x)$ and flow cytometry $(y)$ data sets was expressed as $y=(1.15 \pm 0.05) x-(408 \pm$ 1542) ( $\mathrm{r}=0.93, \mathrm{n}=65$ ), where the slope was significantly higher than 1 and the $y$-intercept did not significantly differ from 0 (Student's $t$-test, $\mathrm{p}<0.001$ and $\mathrm{p}>0.05$, respectively). The regression slope was not significantly different between depths of $<200 \mathrm{~m}$ $(1.2 \pm 0.1)$ and $\geq 200 \mathrm{~m}(1.6 \pm 0.2)$ (Student's $t$-test, $\mathrm{p}>$ 0.05). This shows that epifluorescence microscopy underestimated Synechococcus abundance by $15 \%$ though the water column. However, epifluorescence microscopy demonstrated superior reproducibility $(8.5 \%)$ to flow cytometry (average, 29\%) for the samples collected at $\geq 200 \mathrm{~m}$ depths, with abundance in the order of tens of cells $\mathrm{ml}^{-1}$, with much lower procedural blank values $\left(0.021\right.$ cells $\left.\mathrm{ml}^{-1}\right)$ than obtained with flow cytometry (mean $=10$ cells $\mathrm{ml}^{-1}$ ). For this reason, we used epifluorescence microscopy in preference to flow cytometry.

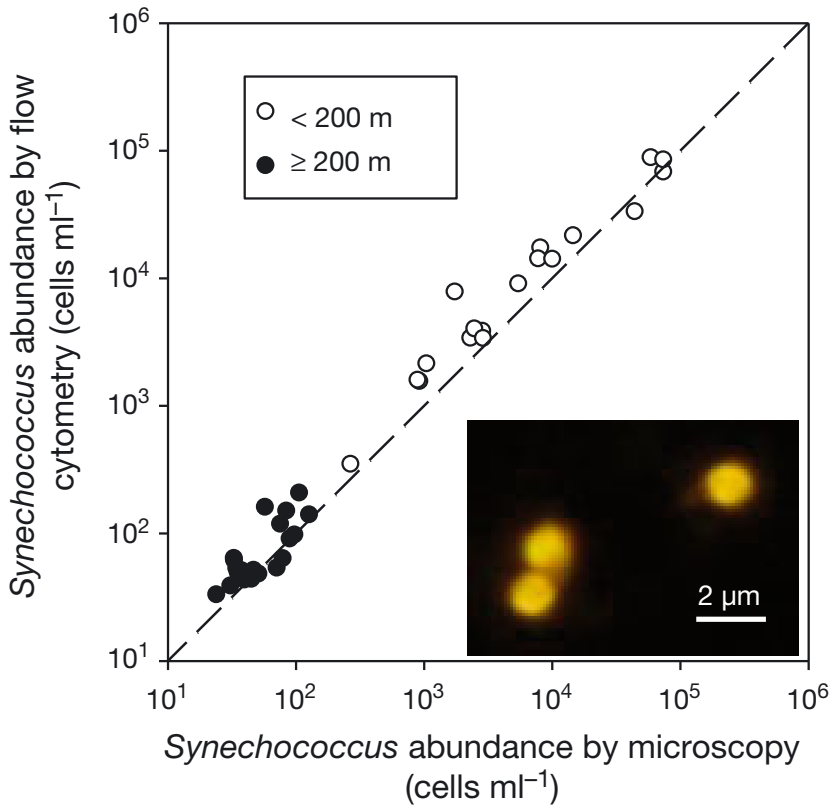

Fig. 1. Comparison of Synechococcus abundance measurements using epifluorescence microscopy and flow cytometry. Samples were taken from depths of 5 to $B-20 \mathrm{~m}$ (20 m above the bottom) at Stn 2 (Suruga Bay) in November 2007 and in February and May 2008. The broken line indicates $y=x$. The relationship over the water column is expressed as $y=(1.15 \pm$ $0.05) x-(408 \pm 1542)(r=0.93, \mathrm{n}=65)$ using Model II linear regression. Note that samples taken in May 2008 were measured in triplicate with flow cytometry. The insert represents Synechococcus cells under blue-excitation of epifluorescence microscopy. The sample was taken at $1000 \mathrm{~m}$ at Stn 2 (Suruga Bay) in May 2008, and $1 \mathrm{l}$ of seawater was filtered through a $25 \mathrm{~mm}$ diameter filter with a pore size of $0.4 \mu \mathrm{m}$ 


\section{Hydrography}

The depth of the euphotic zone was estimated at 31 to $51 \mathrm{~m}$ (Stn 2, Suruga Bay) and 80 to $120 \mathrm{~m}$ (Stn C2700, subtropical NW Pacific) during previous cruises (Table 1). Winter MLD was 86 to $133 \mathrm{~m}$ (Stn 2) and 47 and $90 \mathrm{~m}$ (Stn C2700). There were salinity minima at 380 to $520 \mathrm{~m}$ (Stn 2) and $680 \mathrm{~m}$ (Stn C2700), where potential density anomaly $\left(\sigma_{\theta}\right)$ was around 26.9 and 26.7, respectively (Fig. 2). These salinity minima are considered as the upper part of the North Pacific Intermediate Water (NPIW, Talley et al. 1995). Salinity of NPIW was notably low in the Suruga Bay in July 2006, suggesting an occasional intrusion of substantial volumes of NPIW. The subsurface salinity maximum was observed at around $100 \mathrm{~m}$ at Stn 2 and was accounted for as a mixture of coastal water and the Kuroshio Water (Iwata et al. 2005). For Stn C2700, the subsurface salinity maximum at $120 \mathrm{~m}$ is considered to be due to the North Pacific Tropical Water formed at $20^{\circ}$ to $30^{\circ} \mathrm{N}$ latitude and $140^{\circ} \mathrm{E}$ to $160^{\circ} \mathrm{W}$ longitude (Qu \& Mitsudera 1999, Suga et al. 2000). The core of the Kuroshio main stream was situated at around $32^{\circ} 30^{\prime} \mathrm{N}$ along the meridian of Stns 2 and C2700.

\section{Vertical profiles}

Synechococcus abundance decreased exponentially from the surface ( 2 or $5 \mathrm{~m}$ ) to $200 \mathrm{~m}$, falling to $0.060 \%$ (May 2008) and 9.7\% (April 2006) of the surface abun- dance at Stn 2 (Fig. 3). Surprisingly, Synechococcus abundance was more or less constant at depths of $200 \mathrm{~m}$ and below (coefficient of variation, 30\%) regardless of season, and a similar profile was also observed at Stn C2700 (Fig. 4). In contrast, total prokaryotic abundance and chl a concentration generally decreased with increasing depth below $200 \mathrm{~m}$ despite the contribution of Synechococcus cells.

To compare these profiles more precisely, we calculated the ratios of abundance (or concentration) between the upper end $(200 \mathrm{~m})$ and the lower end $(1000 \mathrm{~m})$ of the mesopelagic zone. Comparison of correlation coefficients was not made because of the small sample size of each series of profiles ( $\mathrm{n}=3$ to 7). The ratios of Synechococcus at $200 \mathrm{~m}$ to $1000 \mathrm{~m}$ were not significantly different from 1 (Student's $t$-test, $\mathrm{p}>0.05)$, while the ratios were significantly greater than 1 for total prokaryotes (Student's $t$-test, $\mathrm{p}<0.001$ ) and chl a (sign test, p < 0.01); the latter 2 measures showed a significant decrease from $200 \mathrm{~m}$ to $1000 \mathrm{~m}$ (Fig. 5A). Moreover, the ratios of abun-

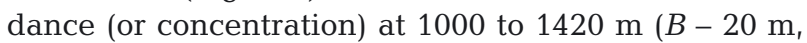
Stn 2) or to 2000 m (Stn C2700) were not significantly different from 1 for Synechococcus or chl a (Student's $t$-test, $\mathrm{p}>0.05$ ), while the ratios were significantly higher than 1 for total prokaryotes (sign test, $\mathrm{p}<0.05$ ) (Fig. 5B). Thus, a vertically constant distribution was confirmed only for Synechococcus in the mesopelagic and the upper bathypelagic zones. It should be noted that the ratio for the upper bathypelagic chl a was less than 1 at Stn 2 in April 2007 and May 2008, since
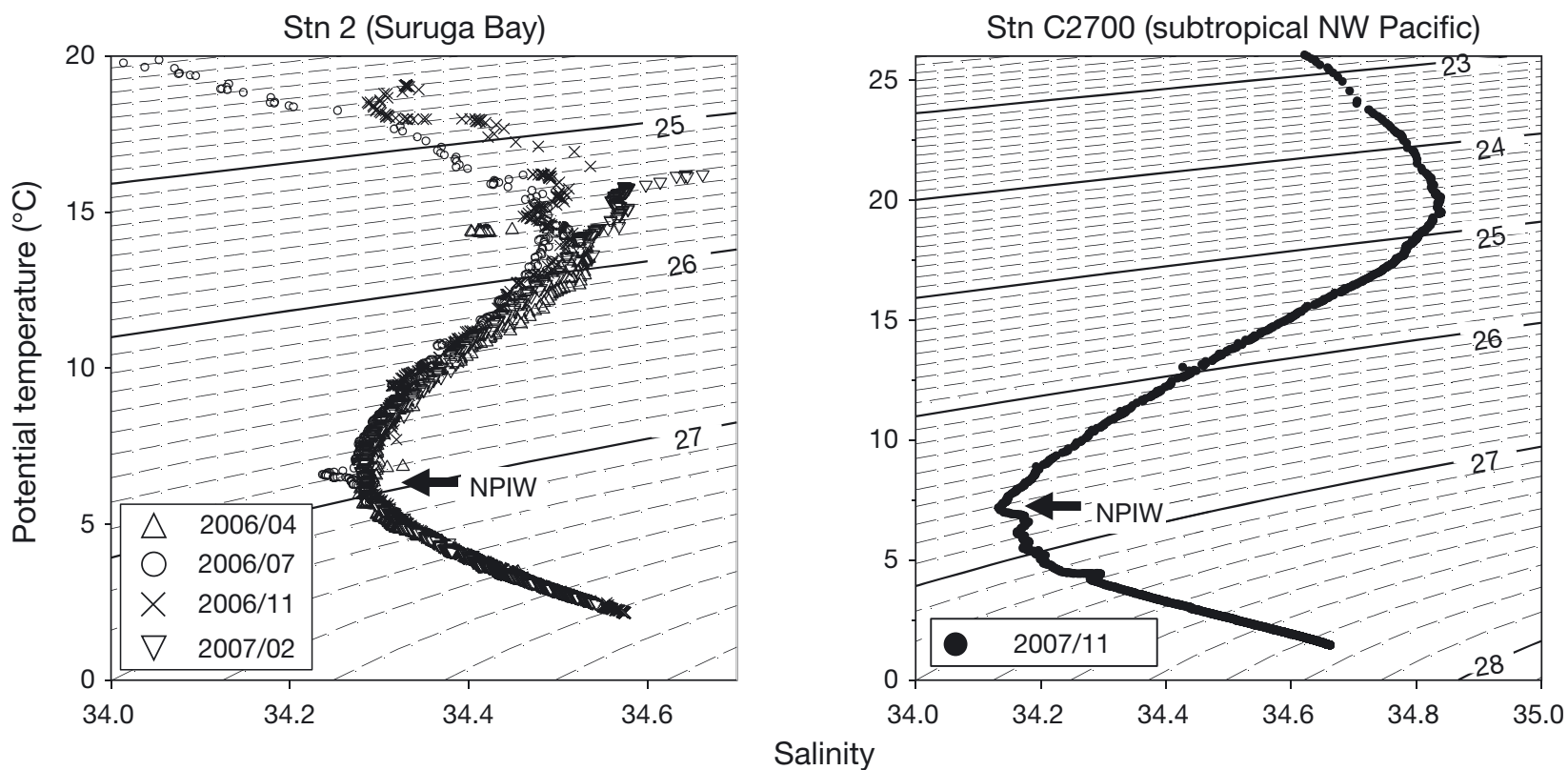

Fig. 2. Temperature-salinity diagrams at Stn 2 (Suruga Bay) and Stn C2700 (subtropical NW Pacific). Solid and broken lines show contours of potential density anomaly $\left(\sigma_{\theta}\right)$. Arrows indicate the water mass showing the signature of the North Pacific Intermediate Water (NPIW) 

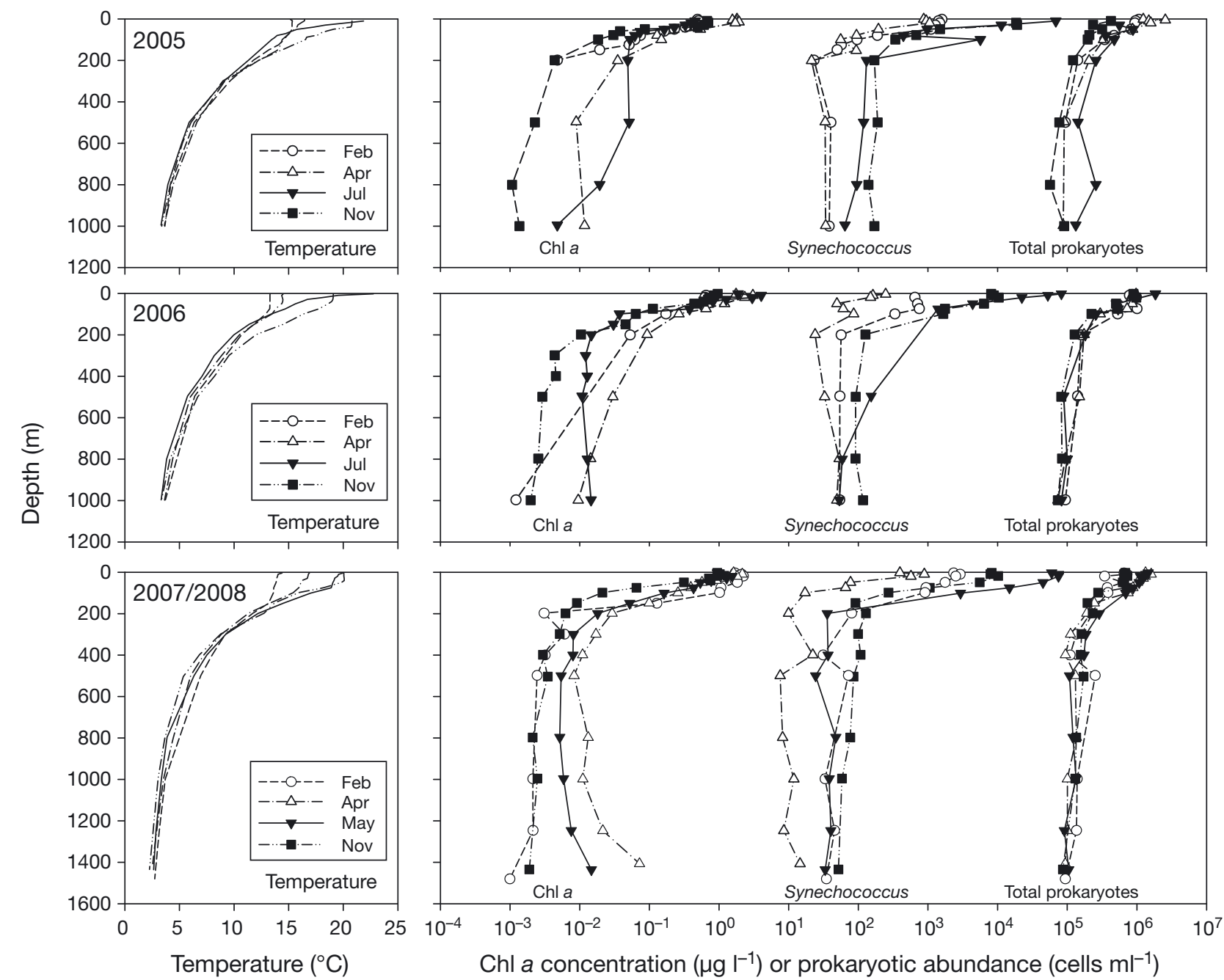

Fig. 3. The top $1000 \mathrm{~m}$-depth profiles $(2005,2006)$ and full-depth profiles $(2007 / 2008)$ of temperature, chl a concentration, Synechococcus and total prokaryote abundances at Stn 2 (Suruga Bay). Profiles of chl a and total prokaryotes in Feb 2005 were obtained in the top $200 \mathrm{~m}$ and $500 \mathrm{~m}$, respectively. The procedural blank was $0.021 \mathrm{cells} \mathrm{ml}^{-1}\left(\right.$ Synechococcus), $1.1 \times 10^{4}$ cells ml ${ }^{-1}$ (total prokaryotes) and $2.0 \times 10^{-4} \mathrm{\mu g}^{-1}(\mathrm{chl} \mathrm{a})$ at $\geq 200 \mathrm{~m}$. Symbols are omitted for temperature

chl a increased with increasing depth below $1000 \mathrm{~m}$ (Fig. 3), suggesting a release of phytoplankton from a nepheloid layer.

Relative cellular contents of chl a and PE among Synechococcus cells, which are represented by red and orange fluorescence intensities, respectively, in flow cytometry (Six et al. 2004) were low at $2 \mathrm{~m}$, increased with increasing depth down to $50 \mathrm{~m}$, and then decreased down to $100 \mathrm{~m}$, similarly to the results for PE in the NE Atlantic (Olson et al. 1990) (Fig. 6). The increase in PE in the upper $50 \mathrm{~m}$ can be explained by phytoacclimation, and the decrease below $50 \mathrm{~m}$ might reflect an unhealthy state caused by low light. $\mathrm{Chl} a$ and PE fluorescence varied considerably at $200 \mathrm{~m}$ and below but was within a similar range to the fluorescence levels seen in the top $100 \mathrm{~m}$. This finding suggests that the deep Synechococcus population is composed of cells with a variety of pigment levels and that at least a proportion of the cells retain pigments in prolonged darkness.

\section{Seasonal and regional differences}

While Synechococcus abundance was constant at depths of $200 \mathrm{~m}$ and below (deep water), it did vary with season and study area (Figs. $3 \& 4$ ). Deep Synechococcus was more abundant in summer and fall (24 to 190 cells ml${ }^{-1}$ ) than in spring ( 7.6 to $49 \mathrm{cells} \mathrm{ml}^{-1}$ ) in accordance with the seasonal changes in the epipelagic zone (Fig. 3). Averaged Synechococcus abundance at $\geq 200 \mathrm{~m}$ depths was marginally significantly correlated with Synechococcus abundance at $10 \mathrm{~m}(\mathrm{r}=$ 0.59; Student's $t$-test, $\mathrm{p}=0.07$ ) (Fig. 7A). The highest 

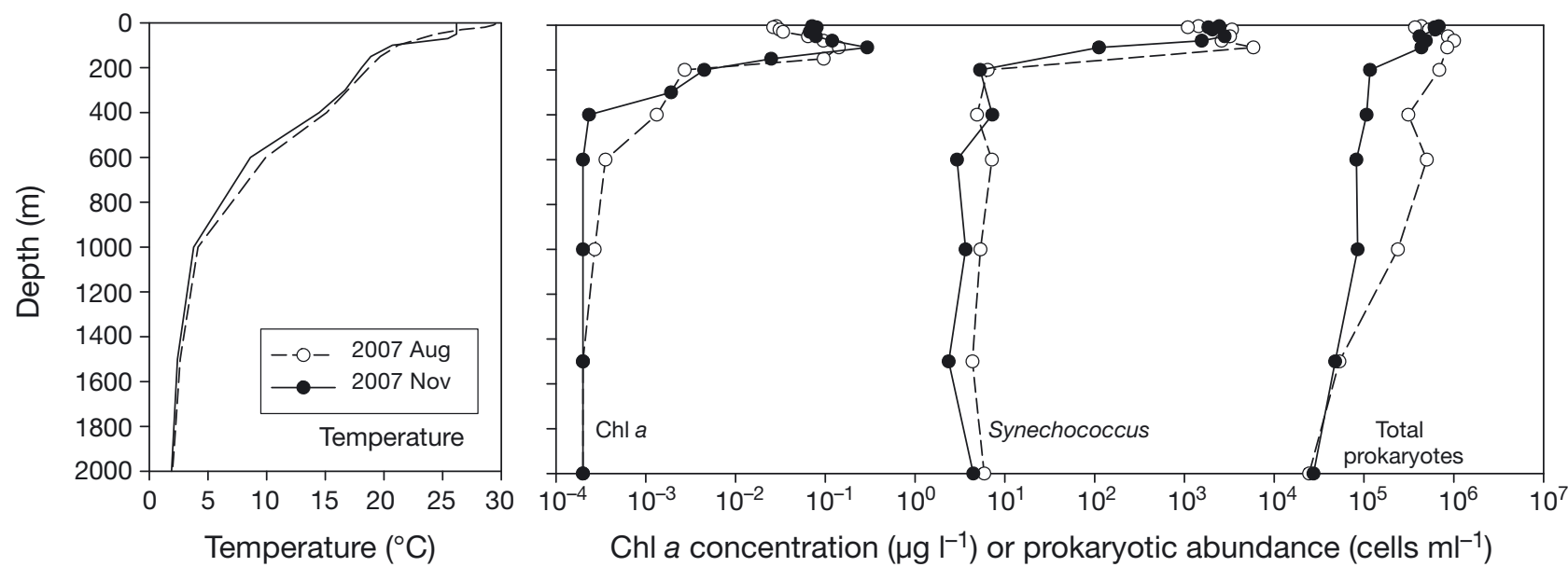

Fig. 4. Depth profiles of temperature, chl a concentration, Synechococcus and total prokaryote abundances at Stn C2700 (subtropical NW Pacific) in 2007. The procedural blank was 0.021 cells ml $^{-1}$ (Synechococcus), $1.1 \times 10^{4} \mathrm{cells} \mathrm{ml}^{-1}$ (total prokaryotes) and $2.0 \times 10^{-4} \mathrm{gg} \mathrm{l}^{-1}(\mathrm{chl} \mathrm{a})$ at $\geq 200 \mathrm{~m}$, and chl a concentration below the procedural blank was set at $2.0 \times 10^{-4} \mu \mathrm{g}^{-1}$. Symbols are omitted for temperature

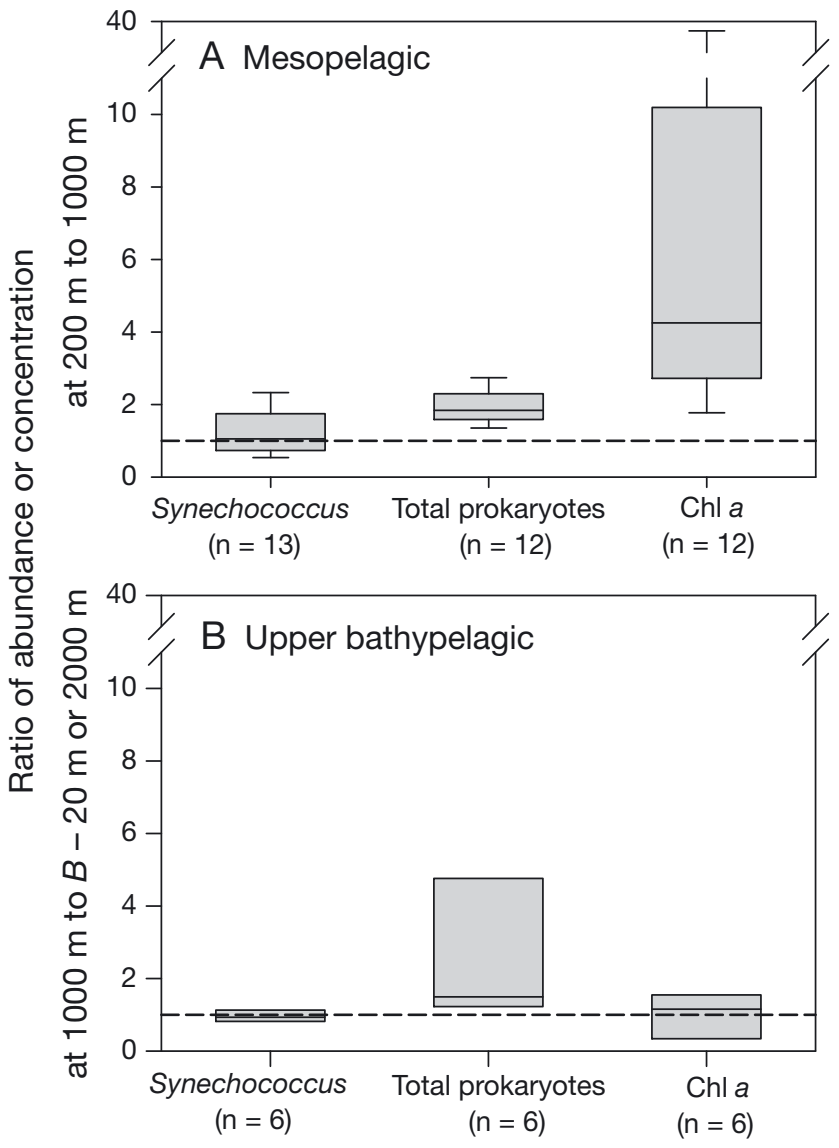

Fig. 5. Box plots of (A) the ratios of prokaryote abundance and chl a concentration at 200 to $1000 \mathrm{~m}$ and (B) at $1000 \mathrm{~m}$ to $20 \mathrm{~m}$ above the bottom (Stn 2, Suruga Bay) or to $2000 \mathrm{~m}$ (Stn C2700, subtropical NW Pacific). Upper and lower ends of boxes show 75 and $25 \%$ confidence intervals (CI), and upper and lower ends of error bars show 90 and $10 \%$ CI, respectively. Solid lines in boxes show medians. The broken line indicates a ratio of 1 . Sample size is given in parentheses abundance of epipelagic Synechococcus occurred in May and July, consistent with annual variations in Synechococcus abundance in La Jolla, California (Tai \& Palenik, 2009), but different from that seen at oligotrophic oceanic sites (Malmstrom et al. 2010). The greater abundance in summer was related to high temperature (Table 2), as shown in many earlier studies (Agawin et al. 1998, Sommaruga et al. 2005, Jing et al. 2009). Chl a exhibited different seasonal changes from Synechococcus, with higher concentrations in spring and lower concentrations in fall throughout the water column, though the correlation was not significant between $10 \mathrm{~m}$ and $\geq 200 \mathrm{~m}$ ( $\mathrm{r}=0.28$, p > 0.3; Fig. 7C). Seasonal variations in total prokaryotes were much smaller than those in Synechococcus and chl $a$, and abundance was not correlated between $10 \mathrm{~m}$ and $\geq 200$ $\mathrm{m}(\mathrm{r}=0.33, \mathrm{p}>0.3$; Fig. 7B). Deep Synechococcus abundance was roughly 10 -fold lower at Stn C2700 ( 2.4 to 7.2 cells $\mathrm{ml}^{-1}$ ) than at Stn 2 , although the surface abundance was within a similar range. In contrast, total prokaryotic abundance at Stn $2\left(0.056 \times 10^{6}\right.$ to 1.2 $\times 10^{6}$ cells ml $\left.^{-1}\right)$ and Stn C2700 (0.087 $\times 10^{6}$ to $1.0 \times 10^{6}$ cells $\mathrm{ml}^{-1}$ ) was relatively similar throughout the water column. Chl a concentration was roughly 10 -fold lower at Stn C2700 $\left(<0.0002\right.$ to $\left.0.29 \mu \mathrm{g} \mathrm{l}^{-1}\right)$ than at Stn 2 $\left(0.0011\right.$ to $\left.4.0 \mu \mathrm{g} \mathrm{l}^{-1}\right)$, and was below the procedural blank value at $\geq 1500 \mathrm{~m}$ (August) and $\geq 600 \mathrm{~m}$ (November) at Stn C2700.

\section{Contribution of the deep Synechococcus population to the total population in the water column}

To evaluate the numerical importance of Synechococcus populations in the dark ocean, the contribu- 

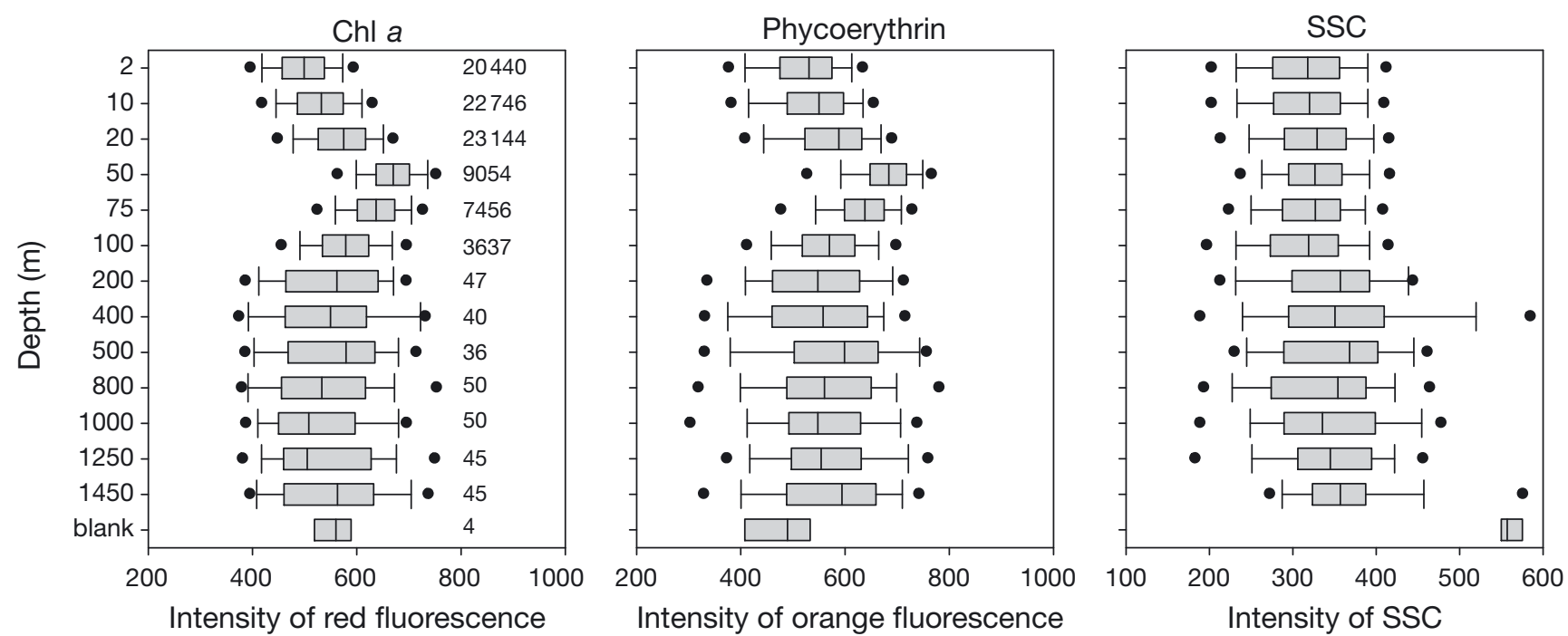

Fig. 6. Box plots of intensities of red (chl a) and orange fluorescence (phycoerythrin) and side scatter (SSC) in Synechococcus cells obtained using flow cytometry in samples collected in May 2008. Data from triplicate analyses were combined. Upper and lower ends of boxes show 75 and $25 \%$ confidence intervals (CI), and upper and lower end of error bars show 90 and $10 \%$ CI, respectively. Dots represent 5 and $95 \%$ CI, and solid lines in boxes show medians. Numbers in the plot of chl a show sample size

tion of Synechococcus at depths of $\geq 200 \mathrm{~m}$ to the total Synechococcus population in the water column was calculated (Fig. 8). When sampling was not conducted near the bottom, depth-integrated abundance at $\geq 200 \mathrm{~m}$ was estimated by multiplying the average abundance at $\geq 200 \mathrm{~m}$ by the water depth minus $200 \mathrm{~m}$. The estimated ratios were quite similar to the estimates from the actual data obtained at Stn 2 in 2007 and 2008 (Fig. 8). The contribution of Synechococcus at $\geq 200 \mathrm{~m}$ ranged from 1 to $77 \%$ at Stn 2, with the highest values occurring in spring (36 to $77 \%$ ) and the lowest in summer (1 to $9 \%)$. The contribution at Stn C2700 was relatively low (4 and 10\%) and similar to the contribution at Stn 2 in summer. The contributions at Stn C2700 were potential maxima because Synechococcus abundance might well decrease below $2000 \mathrm{~m}$.

\section{Incubation experiments}

Synechococcus abundance increased by $40 \%$ during the first $3 \mathrm{~d}$ of the dark incubation experiment (Dark Expt) for cells taken from $20 \mathrm{~m}$ depth (Fig. 9A). This result reveals that Synechococcus can grow for a few days in the dark, presumably by consuming ATP and NADPH produced during exposure to light. Synechococcus populations taken from $20 \mathrm{~m}$ declined rapidly between Day 5 and Day 10 and continued to decrease until Day 30. In contrast, Synechococcus populations taken from $300 \mathrm{~m}$ remained relatively constant over a period of $30 \mathrm{~d}$, and the slope of linear regression between incubation period and abundance was not significantly different from $0(\mathrm{r}=-0.44, \mathrm{p}>0.05)$. Abundance on Day 30 was quite similar between the $20 \mathrm{~m}\left(65\right.$ cells ml $\left.\mathrm{m}^{-1}\right)$ and $300 \mathrm{~m}\left(60\right.$ cells ml$\left.^{-1}\right)$ populations, and accounted for $0.53 \%(20 \mathrm{~m})$ and $77 \%$ (300 m), respectively, of the initial abundance.

In the light manipulation experiment (Light/Dark Expt), abundance of Synechococcus populations taken from $397 \mathrm{~m}$ decreased to $49 \%$ of the initial level in the first $2 \mathrm{~d}$ in a $12 \mathrm{~h}$ light and $12 \mathrm{~h}$ dark cycle, and then increased 220-fold from Day 2 to Day 14 (Fig. 9B). The initial decrease in abundance suggests susceptibility of the deep population to light. Synechococcus abundance remained relatively constant in continuous darkness.

\section{DISCUSSION}

\section{Distribution of Synechococcus}

The most interesting result in this study is the constant vertical abundance profiles of Synechococcus in deep seawater $(\geq 200 \mathrm{~m})$, which occurred regardless of season or study area (Figs. $3 \& 4$ ). In contrast, the vertical distribution of total prokaryotes or chl a was not constant, and a decrease in total prokaryotic abundance with increasing depth probably resulted from a decrease in the supply of organic substrates via sinking flux (Sohrin et al. 2010). Synechococcus strains can photosynthesize at a minimum irradiance of $2 \mu \mathrm{mol}$ photons $\mathrm{m}^{-2} \mathrm{~s}^{-1}$ (Six et al. 2004, Timmermans et al. 2005), which corresponds to the PAR level at $60 \mathrm{~m}$ in 

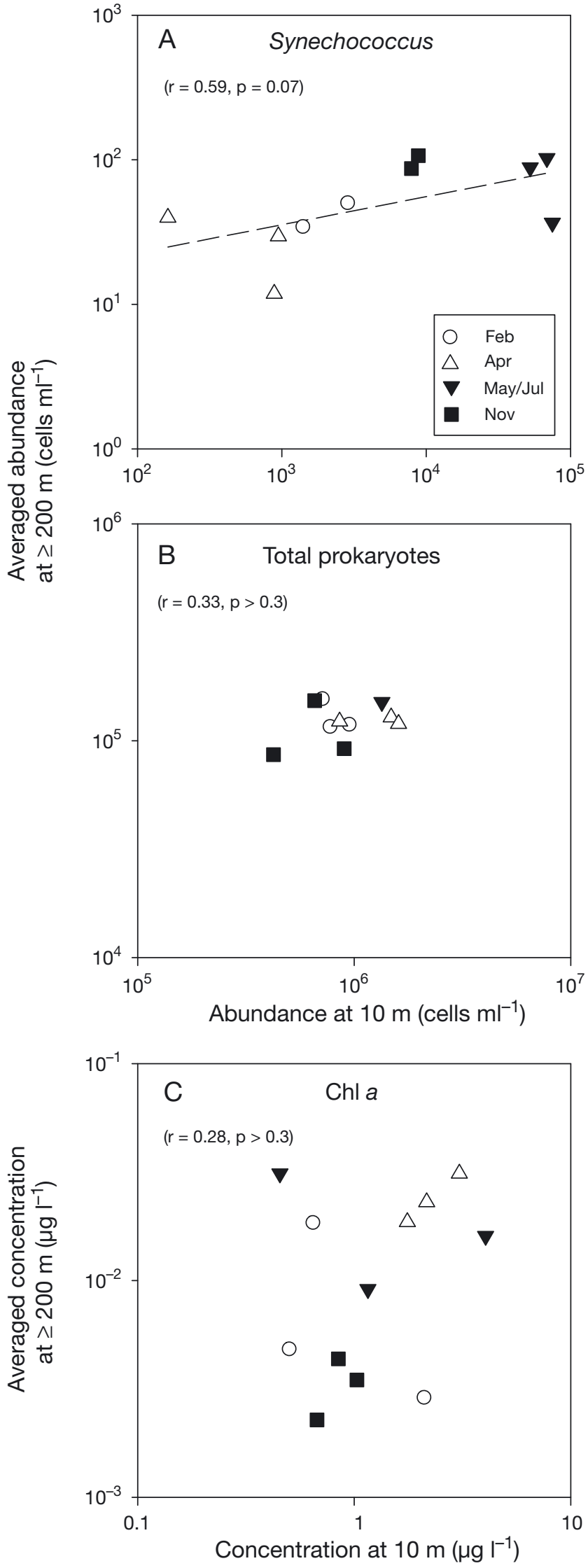

Fig. 7. Comparison of (A) Synechococcus and (B) total prokaryote abundance, and (C) chl a concentration at $10 \mathrm{~m}$ to the averages at depths of $\geq 200 \mathrm{~m}$. Correlation coefficient (r) and results of Student's $t$-test (p) are shown in parentheses. The broken line was fitted by linear regression

the Suruga Bay in April 2001, and we infer the irradiance is so low at $\geq 200 \mathrm{~m}$ that the photosynthetic activity of Synechococcus would be negligible. Vilibi \& Šanti (2008) reported a downward export of Synechococcus to the sea floor $(1150 \mathrm{~m})$ in the south Adriatic Sea through a combination of winter convection and density currents on the downslope. At the sites in the present study, winter MLD is so shallow ( $\leq 133 \mathrm{~m}$, Table 1$)$ that Synechococcus would be unlikely to sink as a result of winter convection. Regarding the possibility of lateral transport, NPIW intruded at around $450 \mathrm{~m}$ (Stn 2) and $680 \mathrm{~m}$ (Stn C2700) (Fig. 2). There are no available data on Synechococcus abundance in NPIW, but the unique formation process of NPIW explains the different Synechococcus abundances between NPIW and adjacent water masses. NPIW is formed in the interfrontal zone between the Oyashio Front and the Kuroshio Extension, and consists of the Kuroshio and Oyashio waters (Talley et al. 1995, Yasuda et al. 1996). NPIW did not appear to influence the levels of Synechococcus. This finding may be partly due to a lack of sampling in the core of NPIW, but the synchronized seasonal changes in Synechococcus between $10 \mathrm{~m}$ and $\geq 200 \mathrm{~m}$ at Stn 2 (Fig. 7A) strongly suggest that the distributions of deep Synechococcus are influenced by vertical transport of the epipelagic populations rather than lateral transport in our study area. This hypothesis is supported by many previous studies that have detected Synechococcus cells on sinking particles (Vanucci et al. 2001 and references therein). Richardson \& Jackson (2007) showed that picophytoplankton can sink from the epipelagic zone even without large carrier particles, by aggregating into cell clumps. However, given that the highest contribution of Synechococcus at $\geq 200 \mathrm{~m}$ at $\mathrm{Stn} 2$ was seen in spring, it seems that transport of Synechococcus mainly occurred by attachment to larger particles, such as microphytoplankton, and that self-aggregation in the epipelagic zone would be less effective in spring due to the lower total abundance observed at this time. We did not find fluorescent phytodetritus in deep seawater samples with epifluorescence microscopy, and phytodetritus may in fact hydrolyze in the water column. Copepods and salps can ingest Synechococcus cells attached to microphytoplankton and transport them to greater depths by packing them into rapidly sinking fecal pellets (Turner 2002 and references therein). Other possible carriers are mineral particles and appendicularian houses. Appendicularians are found 


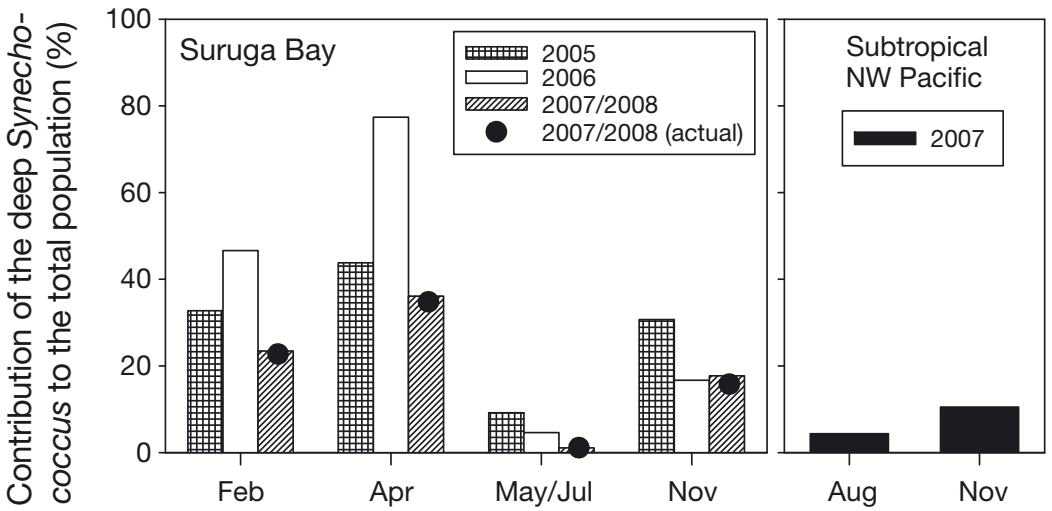

Fig. 8. Contribution of Synechococcus abundance in the deep seawater (200 m to bottom) to the total abundance in the water column. Values were calculated as the ratios of depth-integrated abundance. Bars indicate the ratios, in which abundance at $\geq 200 \mathrm{~m}$ was represented by averages, and dots show the ratios of actual data

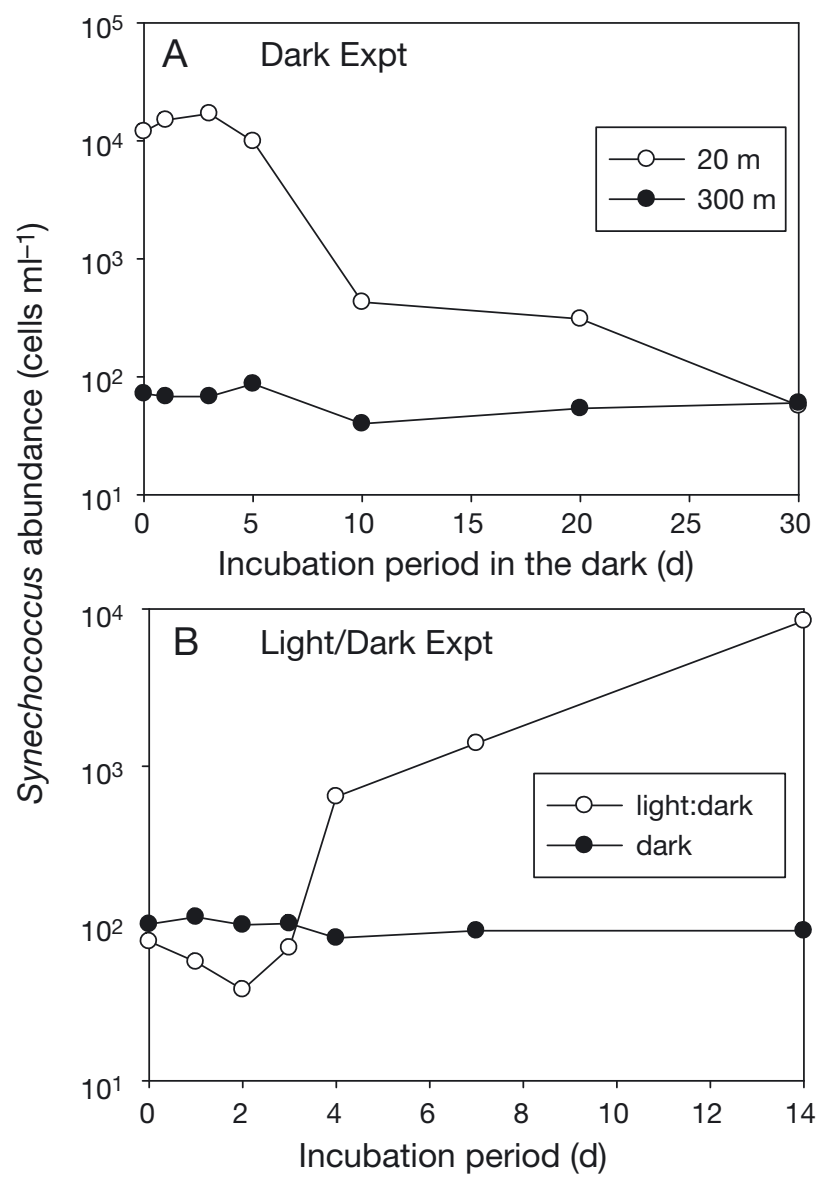

Fig. 9. Time course of Synechococcus abundance during incubation experiments using (A) seawater from $20 \mathrm{~m}$ and $300 \mathrm{~m}$ performed in constant darkness (Dark Expt) and (B) seawater from $397 \mathrm{~m}$ in a cycle of $12 \mathrm{~h}$ light:12 $\mathrm{h}$ dark and continuous darkness (Light/Dark Expt). Seawater was collected in November 2005 (Dark Expt) and October 2006 (Light/Dark Expt) in the Suruga Bay and filtered before the experiments to remove grazers in the surface layer in the Suruga Bay throughout most of the year (Itoh 1990), and Synechococcus cells have been reported to adhere to their houses (Silver et al. 1998). Synechococcus readily adheres to mineral particles; it can attach to glass slides placed in seawater faster than other phytoplankton (Nayar et al. 2005). The contribution of Synechococcus at $\geq 200 \mathrm{~m}$ was extremely low at Stn 2 in summer and at Stn C2700 (Fig. 8). This result implies less effective transport of Synechococcus under stratified and oligotrophic conditions despite the enhanced potential for selfaggregation in nutrient-depleted cells (Klut \& Stockner 1991, Table 2).

If Synechococcus cells are associated with sinking particles which they subsequently detach from, the supply of Synechococcus to the surrounding seawater would decrease exponentially with increasing depth in proportion to the exponential decrease in sinking flux (Martin et al. 1987). However, this hypothesis is not in keeping with our finding of a vertically constant abundance profile. We then applied a cell digestion assay, which enabled cells with intact membranes (live cells) to be distinguished from those with damaged membranes (dead cells) (Darzynkiewicz et al. 1994). We found an overwhelming contribution of live cells (almost 100\%) to total Synechococcus cells with relatively constant levels of live cells through the mesopelagic zone at Stns 2 and C2700 and a rapid removal of dead Synechococcus cells at the beginning of dark incubation experiments, apparently due to autolysis (R. Sohrin, Y. Obara, K. Endoh, R. Handa unpubl. data). We speculate that the vertically constant Synechococcus abundance profiles are related to rapid removal of dead cells and of acclimation of the survivors to the dark, and illustrated our proposed model in Fig. 10. Briefly, a proportion of the dead Synechococcus cells is immediately eliminated from the water column, and their number decreases with increasing depth because of acclimation. The remaining cells distribute evenly as a result.

The mesopelagic Synechococcus abundance did not decrease in the Dark Expt though the surface Synechococcus abundance continued to decrease from Day 3 to Day 30 (Fig. 9A). In a different dark incubation experiment, the surface Synechococcus abundance decreased in the first $20 \mathrm{~d}$ and then remained stable until Day 40 (data not shown). These results suggest dark acclimation and/or occurrence of a population with a tolerance to darkness. The vertically constant levels of live cells cannot be explained in this study, and the downward transport of surface Synechococcus 


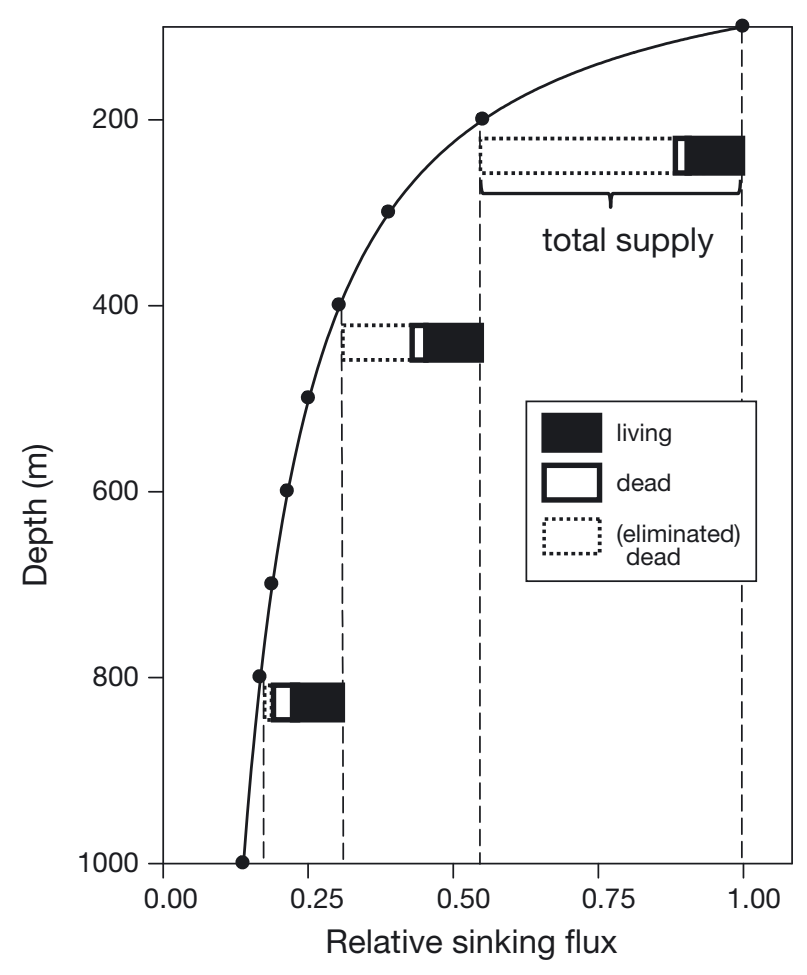

Fig. 10. Proposed Synechococcus transportation model associated with sinking flux. Sinking flux was expressed as ratios of the flux measured at $100 \mathrm{~m}$ depth and fitted to a power function described by Martin et al. (1987). Differences in sinking flux at various depths correspond to the relative amount of Synechococcus supplied by the sinking flux to the surrounding water in a corresponding depth stratum. Supplied Synechococcus includes dead cells, a part of which is immediately

eliminated by autolysis, leaving behind mostly live cells

populations by sinking flux remains hypothetical. Uncovering the link between the epipelagic and deep Synechococcus populations using molecular genetic approaches and physiological studies of isolates might help explain the observed Synechococcus profiles.

\section{Physiological state of Synechococcus in the dark ocean}

The relative cellular contents of chl $a$ and PE among Synechococcus cells were found to be within a similar range of between $<100 \mathrm{~m}$ and $\geq 200 \mathrm{~m}$ for Synechococcus (Fig. 6), and the mesopelagic Synechococcus population was grown in a light/dark cycle (Fig. 9B). These results suggest that at least a proportion of the deep Synechococcus cells is viable and retains its pigments in prolonged darkness.

Many previous studies have shown that Synechococcus in epipelagic waters can incorporate exogenous amino acids but at a lower rate than Prochlorococcus (Zubkov et al. 2003, Zubkov \& Tarran 2005). Several
Synechococcus strains have ectoproteolytic activity (Martinez \& Azam 1993); however, these rates are greatly reduced in the dark (Kramer 1990, Martinez \& Azam 1993, Mary et al. 2008). Lochte \& Turley (1988) incubated phytodetritus taken from the sediment surface (water depth $4500 \mathrm{~m}$ ) with deep sea $\left(450 \mathrm{~atm}, 2^{\circ} \mathrm{C}\right.$ ) or surface water $\left(1 \mathrm{~atm}, 15^{\circ} \mathrm{C}\right)$ conditions in the dark and detected a 4 -fold increase in Synechococcus abundance on Day 1 under both conditions. The relatively constant abundance of mesopelagic Synechococcus during the dark incubation suggests a limitation on Synechococcus growth caused by restricted availability of dissolved organic substrates.

Some genera of cyanobacteria can survive in the dark by catabolizing cellular storage molecules such as carbohydrates, lipids and proteins (Osanai et al. 2005, Montechiaro et al. 2006). In the case of Phormidium autumnale, about $50 \%$ of endogenous organic carbon is catabolized after $21 \mathrm{~d}$ and cell size is halved (Montechiaro et al. 2006). Side scatter light (SSC) of flow cytometry is related to cellular contents and cell size for prokaryotes and picophytoplankton (Wittrup et al. 1988, Jochem 2000). In the present study, SSC of Synechococcus was higher in the mesopelagic than in the epipelagic (Mann-Whitney $U$-test, p < 0.001; Fig. 6), which does not support the idea of a survival mechanism involving the catabolism of assimilated carbon in the mesopelagic. Synechococcus sp. WH7803 can uptake leucine and uracil in the dark for at least $24 \mathrm{~h}$, though incorporation is suppressed (Kramer 1990). Further study would be required to determine whether exogenous organic compounds meet the energy demands of Synechococcus in deep seawater or whether the rates of metabolism of deep Synechococcus cells fall to lower levels, as is seen in some strains of chlorophytes and prymnesiophytes (Jochem 1999).

\section{Ecological and biogeochemical implications for Synechococcus in the deep ocean}

Although the mesopelagic Synechococcus populations collected in November 2005 did not decline significantly in the Dark Expt, the in situ population decreased from November to February. This difference may reflect the removal of in situ Synechococcus populations by grazing. Predation by cyanophages removes Synechococcus from epipelagic waters (Suttle \& Chan 1993, 1994), but the constant abundance seen in the incubation experiments suggests this had little effect on the deep Synechococcus population, presumably due to the kill the winner hypothesis (Thingstad 2000), since its abundance was low at greater depths. From the differences in the average Synechococcus 
abundance at $\geq 200 \mathrm{~m}$ at Stn 2 between November and February, grazing rates were estimated at 0.0069 to $0.014 \mathrm{~d}^{-1}$ (average, $0.013 \mathrm{~d}^{-1}$ ). This is likely to be a low value, because the replenishment of Synechococcus cells caused by sinking flux was not taken into account. By dividing the grazing rate by the depthweighted average of heterotrophic nanoflagellates (HNF) or ciliate abundance in the 200 to $1000 \mathrm{~m}$ range at Stn 2 for November and February $\left(2.8 \times 10^{4}\right.$ cells $1^{-1}$ and 12 cells $\mathrm{l}^{-1}$, respectively, Imazawa 2006), clearance rates of HNF and ciliates on the mesopelagic Synechococcus were roughly estimated at 8.6 to $17 \mathrm{nl}$ $\mathrm{HNF}^{-1} \mathrm{~h}^{-1}$ and 25 to $50 \mu \mathrm{l}$ ciliate ${ }^{-1} \mathrm{~h}^{-1}$, respectively. The former estimate is within the range of clearance rates of HNF on Synechococcus in subsurface seawater $(0.5$ to $25 \mathrm{nl} \mathrm{HNF}^{-1} \mathrm{~h}^{-1}$, Christaki et al. 2001) and on prokaryotes in mesopelagic seawater (1 to $16 \mathrm{nl} \mathrm{HNF}^{-1}$ $\mathrm{h}^{-1}$, Cho et al. 2000). On the other hand, the latter estimate is 1 to 3 orders of magnitude higher than the clearance rates of ciliates on Synechococcus in epipelagic waters (10 to $3150 \mathrm{nl}$ ciliate ${ }^{-1} \mathrm{~h}^{-1}$; Šimek et al. 1995, Christaki et al. 1998, 1999, Tsai et al. 2007), so we contend that ciliates are not a significant Synechococcus predator in the mesopelagic Suruga Bay. McCarthy et al. $(1998,2004)$ compared D/L ratio of alanine and $\delta^{13} \mathrm{C}$ of D-alanine between Synechococcus bacillaris and ultrafiltered dissolved organic matter (DOM) in the central Pacific, and they suggested that cyanobacteria are the dominant source of DOM throughout the water column. The grazing of HNF on Synechococcus is a mechanism that could supply cyanobacterial organic matter to the mesopelagic DOM pool. Although the abundance and ecological importance of deep Synechococcus populations are much lower than that of their surface counterparts and of heterotrophic prokaryotes in the deep ocean, they nonetheless contribute to the food web and biogeochemical cycles more significantly than previously hypothesized.

Acknowledgements. We are grateful to the captains, officers, crews and scientists on board the RV 'Suruga-maru' and RV 'Soyo-maru', and the staff members of Shizuoka Prefectural Research Institute of Fisheries and National Research Institute of Fisheries Science for their support during cruises. Special thanks are given to T. Hanai and R. Matsuura (Shizuoka Prefectural Research Institute of Fisheries) for their assistance in siphon-sampling and arranging the cruises, and to the Institute for Genetic Research and Biotechnology, Shizuoka University, for the use of their flow cytometer. We also thank our anonymous reviewers for their valuable comments. This work was supported by a grant from the Ministry of Education, Science, Sports and Culture, Japan (19710009), and the cruises of the RV 'Soyo-maru' were supported by a project fund for 'Evaluation, Adaptation and Mitigation of Global Warming in Agriculture, Forestry and Fisheries: Research and Development' financed by the Agriculture, Forestry and Fisheries Research Council.

\section{LITERATURE CITED}

Agawin NSR, Duarte CM, Agustí S (1998) Growth and abundance of Synechococcus sp. in a Mediterranean Bay: seasonality and relationship with temperature. Mar Ecol Prog Ser 170:45-53

Cho BC, Na SC, Choi DH (2000) Active ingestion of fluorescently labeled bacteria by mesopelagic heterotrophic nanoflagellates in the East Sea, Korea. Mar Ecol Prog Ser 206:23-32

> Christaki U, Dolan JR, Pelegri S, Rassoulzadegan F (1998) Consumption of picoplankton-size particles by marine ciliates: effects of physiological state of the ciliate and particle quality. Limnol Oceanogr 43:458-464

Christaki U, Jacquet S, Dolan JR, Vaulot D, Rassoulzadegan F (1999) Growth and grazing on Prochlorococcus and Synechococcus by two marine ciliates. Limnol Oceanogr 44: 52-61

Christaki U, Giannakourou A, van Wambeke F, Grégori G (2001) Nanoflagellate predation on auto- and heterotrophic picoplankton in the oligotrophic Mediterranean Sea. J Plankton Res 23:1297-1310

Church MJ, Jenkins BD, Karl DM, Zehr JP (2005) Vertical distributions of nitrogen-fixing phylotypes at Stn ALOHA in the oligotrophic North Pacific Ocean. Aquat Microb Ecol 38:3-14

Cottrell MT, Kirchman DL (2009) Photoheterotrophic microbes in the Arctic Ocean in summer and winter. Appl Environ Microbiol 75:4958-4966

Darzynkiewicz Z, Li X, Gong J (1994) Assays of cell viability: discrimination of cells dying by apoptosis. In: Darzynkiewicz Z, Robinson JP, Crissman HA (eds) Methods in cell biology, Vol 41. Academic Press, London, p 15-38

Fuhrman JA, Sleeter TD, Carlson CA, Proctor LM (1989) Dominance of bacterial biomass in the Sargasso Sea and its ecological implications. Mar Ecol Prog Ser 57: 207-217

> Gutiérrez-Rodríguez A, Latasa M, Estrada M, Vidal M, Marrasé C (2010) Carbon fluxes through major phytoplankton groups during the spring bloom and post-bloom in the Northwestern Mediterranean Sea. Deep-Sea Res I 57: 486-500

Havskum H, Schlüter L, Scharek R, Berdalet E, Jacquet S (2004) Routine quantification of phytoplankton groups microscopy or pigment analyses? Mar Ecol Prog Ser 273: $31-42$

Imazawa M (2006) Distribution of bacteria, heterotrophic nanoflagellates and ciliates in the central Pacific and Suruga Bay. MSc thesis, Shizuoka University

Itoh H (1990) Seasonal variation of appendicularian fauna off Miho Peninsula, Suruga Bay, central Japan. Bull Plankton Soc Japan 36:111-119

Iwata T, Shinomura Y, Natori Y, Igarashi Y, Sohrin R, Suzuki $\mathrm{Y}$ (2005) Relationship between salinity and nutrients in the subsurface layer in the Suruga Bay. J Oceanogr 61: 721-732

> Jing H, Zhang R, Pointing SB, Liu H, Qian P (2009) Genetic diversity and temporal variation of the marine Synechococcus community in the subtropical waters of Hong Kong. Can J Microbiol 55:311-318

> Jochem FJ (1999) Dark survival strategies in marine phytoplankton assessed by cytometric measurement of metabolic activity with fluorescein diacetate. Mar Biol 135: 721-728

Jochem FJ (2000) Probing the physiological state of phytoplankton at the single-cell level. Sci Mar 64:183-195

Johnson PW, Sieburth JM (1979) Chroococcoid cyanobacteria 
in the sea: a ubiquitous and diverse phototrophic biomass. Limnol Oceanogr 24:928-935

Klut ME, Stockner JG (1991) Picoplankton associations in an ultra-oligotrophic lake on Vancouver Island, British Columbia. Can J Fish Aquat Sci 48:1092-1099

Kramer JG (1990) The effect of irradiance and specific inhibitors on protein and nucleic acid synthesis in the marine cyanobacterium Synechococcus sp. WH 7803. Arch Microbiol 154:280-285

Levitus S (1982) Climatological atlas of the world ocean. In: NOAA Professional Paper, Vol 13. US Governmental Print Office, Washington, DC

> Lochte K, Turley CM (1988) Bacteria and cyanobacteria associated with phytodetritus in the deep sea. Nature 333: 67-69

Malmstrom RR, Coe A, Kettler GC, Martiny AC, Frias-Lopez J, Zinser ER, Chisholm SW (2010) Temporal dynamics of Prochlorococcus ecotypes in the Atlantic and Pacific oceans. ISME J 4:1252-1264

Martin JH, Knauer GA, Karl DM, Broenkow WW (1987) VERTEX: carbon cycling in the northeast Pacific. Deep-Sea Res A 34:267-285

Martinez J, Azam F (1993) Aminopeptidase activity in marine chroococcoid cyanobacteria. Appl Environ Microbiol 59: 3701-3707

Mary I, Tarran GA, Warwick PE, Terry MJ, Scanlan DJ, Burkill PH, Zubkov MV (2008) Light enhanced amino acid uptake by dominant bacterioplankton groups in surface waters of the Atlantic Ocean. FEMS Microbiol Ecol 63: $36-45$

McCarthy MD, Hedges JI, Benner R (1998) Major bacterial contribution to marine dissolved organic nitrogen. Science 281:231-234

> McCarthy MD, Benner R, Lee C, Hedges JI, Fogel ML (2004) Amino acid carbon isotopic fractionation patterns in oceanic dissolved organic matter: an unaltered photoautotrophic source for dissolved organic nitrogen in the ocean? Mar Chem 92:123-134

> Michaels AF, Silver MW (1988) Primary production, sinking fluxes and the microbial food web. Deep-Sea Res A 35: 473-490

Montechiaro F, Hirschmugl CJ, Raven JA, Giordano M (2006) Homeostasis of cell composition during prolonged darkness. Plant Cell Environ 29:2198-2204

Nayar S, Goh BPL, Chou LM (2005) Settlement of marine periphytic algae in a tropical estuary. Estuar Coast Shelf Sci 64:241-248

> Neveux J, Lantoine F (1999) Phycoerythrins in the southern tropical and equatorial Pacific Ocean: evidence for new cyanobacterial types. J Geophys Res 104:3311-3321

Olson RJ, Chisholm SW, Zettler ER, Armbrust EV (1990) Pigments, size, and distribution of Synechococcus in the North Atlantic and Pacific Oceans. Limnol Oceanogr 35: $45-58$

> Osanai T, Kanesaki Y, Nakano T, Takahashi H and others (2005) Positive regulation of sugar catabolic pathways in the cyanobacterium Synechocystis sp. PCC 6803 by the group $2 \sigma$ factor SigE. J Biol Chem 280:30653-30659

Porter KG, Feig YS (1980) The use of DAPI for identifying and counting aquatic microflora. Limnol Oceanogr 25:943-948

Putland JN, Rivkin RB (1999) Influence of storage mode and duration on the microscopic enumeration of Synechococcus from a cold coastal ocean environment. Aquat Microb Ecol 17:191-199

Qu T, Mitsudera H (1999) A climatology of the circulation and water mass distribution near the Philippine coast. J Phys Oceanogr 29:1488-1505
Richardson TL, Jackson GA (2007) Small phytoplankton and carbon export from the surface ocean. Science 315: 838-840

Silver MW, Coale SL, Pilskaln CH, Steinberg DR (1998) Giant aggregates: importance as microbial centers and agents of material flux in the mesopelagic zone. Limnol Oceanogr 43:498-507

Šimek K, Bobková J, Macek M, Nedoma J (1995) Ciliate grazing on picoplankton in a eutrophic reservoir during the summer phytoplankton maximum: a study at the species and community level. Limnol Oceanogr 40:1077-1090

Six C, Thomas JC, Brahamsha B, Lemoine Y, Partensky F (2004) Photophysiology of the marine cyanobacterium Synechococcus sp. WH8102, a new model organism. Aquat Microb Ecol 35:17-29

Sohrin R, Imazawa M, Fukuda H, Suzuki Y (2010) Full-depth profiles of prokaryotes, heterotrophic nanoflagellates, and ciliates along a transect from the equatorial to the subarctic central Pacific Ocean. Deep-Sea Res II 57:1537-1550

Sommaruga R, Hofer JS, Alonso-Sáez L, Gasol JM (2005) Differential sunlight sensitivity of picophytoplankton from surface Mediterranean coastal waters. Appl Environ Microbiol 71:2154-2157

Suga T, Kato A, Hanawa K (2000) North Pacific Tropical Water: its climatology and temporal changes associated with the climate regime shift in the 1970s. Prog Oceanogr 47:223-256

Sugisaki H, Nonaka M, Ishizaki S, Hidaka K and others (2010) Status and trends of the Kuroshio region, 2003-2008. In: McKinnell SM, Dagg MJ (eds) Marine ecosystems of the North Pacific Ocean, 2003- 2008. PICES Special Publication 4. North Pacific Marine Science Organization, Sidney, British Columbia, p 330-359

Suttle CA, Chan AM (1993) Marine cyanophages infecting oceanic and coastal strains of Synechococcus: abundance, morphology, cross-infectivity and growth characteristics. Mar Ecol Prog Ser 92:99-109

Suttle CA, Chan AM (1994) Dynamics and distribution of cyanophages and their effect on marine Synechococcus spp. Appl Environ Microbiol 60:3157-3174

Suzuki R, Ishimaru T (1990) An improved method for the determination of phytoplankton chlorophyll using N, Ndimethyl-formamide. J Oceanogr Soc Japan 46:190-194

Tai V, Palenik B (2009) Temporal variation of Synechococcus clades at a coastal Pacific Ocean monitoring site. ISME J 3: 903-915

> Talley LD, Nagata Y, Fujimura M, Iwao T and others (1995) North Pacific Intermediate Water in the Kuroshio/Oyashio mixed water region in Spring, 1989. J Phys Oceanogr 25: 475-501

Thingstad TF (2000) Elements of a theory for the mechanisms controlling abundance, diversity, and biogeochemical role of lytic bacterial viruses in aquatic systems. Limnol Oceanogr 45:1320-1328

Timmermans KR, van der Wagt B, Veldhuis MJW, Maatman A, de Baar HJW (2005) Physiological responses of three species of marine pico-phytoplankton to ammonium, phosphate, iron and light limitation. J Sea Res 53:109-120

Tsai AY, Chiang KP, Chan YF, Lin YC, Chang J (2007) Pigmented nanoflagellates in the coastal western subtropical Pacific are important grazers on Synechococcus populations. J Plankton Res 29:71-77

Turner JT (2002) Zooplankton fecal pellets, marine snow and sinking phytoplankton blooms. Aquat Microb Ecol 27:57-102

Vanucci S, Dell'Anno A, Pusceddu A, Fabiano M, Lampitt RS, Danovaro R (2001) Microbial assemblages associated with sinking particles in the Porcupine Abyssal Plain (NE 
Atlantic Ocean). Prog Oceanogr 50:105-121

$>$ Vaulot D, Courties C, Partensky F (1989) A simple method to preserve oceanic phytoplankton for flow cytometric analyses. Cytometry 10:629-635

Vilibić I, Šanti D (2008) Deep water ventilation traced by Synechococcus cyanobacteria. Ocean Dyn 58:119-125

Waterbury JB, Watson SW, Guillard RRL, Brand LE (1979) Widespread occurrence of a unicellular, marine, planktonic, cyanobacterium. Nature 277:293-294

Wittrup KD, Mann MB, Fenton DM, Tsai LB, Bailey JE (1988) Single-cell light scatter as a probe of refractile body formation in recombinant Escherichia coli. Nat Biotechnol 6: 423-426

Yamaguchi A, Watanabe $\mathrm{Y}$, Ishida $\mathrm{H}$, Harimoto $\mathrm{T}$ and others (2002) Structure and size distribution of plankton commu-

Editorial responsibility: Daniel Vaulot,

Roscoff, France nities down to the greater depths in the western North Pacific Ocean. Deep-Sea Res II 49:5513-5529

Yasuda I, Okuda K, Shimizu Y (1996) Distribution and modification of North Pacific Intermediate Water in the Kuroshio-Oyashio interfrontal zone. J Phys Oceanogr 26: 448-465

Zubkov MV, Tarran GA (2005) Amino acid uptake of Prochlorococcus spp. in surface waters across the South Atlantic Subtropical Front. Aquat Microb Ecol 40: 241-249

Zubkov MV, Fuchs BM, Tarran GA, Burkill PH, Amann R (2003) High rate of uptake of organic nitrogen compounds by Prochlorococcus cyanobacteria as a key to their dominance in oligotrophic oceanic waters. Appl Environ Microbiol 69:1299-1304

Submitted: October 06, 2010; Accepted: March 24, 2011

Proofs received from author(s): May 31, 2011 